\title{
PENGARUH PERCEIVED ORGANIZATIONAL OF SUPPORT, LEADER- MEMBER EXCHANGE, DAN STRES KERJA TERHADAP TURNOVER INTENTION KARYAWAN GENERASI Y DENGAN EMPLOYEE ENGAGEMENT SEBAGAI VARIABEL INTERVENING
}

\author{
(Studi Kasus Pada Karyawan PT BPR Restu Artha Makmur) \\ Franes Pradusuara; Indarto ${ }^{1)}$; Djoko Santoso $^{2)}$ \\ 1) indarto@usm.ac.id; ${ }^{2)}$ Djoko_hw@usm.ac.id
}

\begin{abstract}
ABSTRAK
Penelitian ini bertujuan: (1) Untuk menganalisis pengaruh perceived organizational of support, leader-member exchange, dan stres kerja terhadap employee engagement dan turnover intention; (2) Untuk Menganalisis pengaruh perceived organizational of support, leader-member exchange, dan stres kerja terhadap Turnover Intention dengan dimediasi oleh employee engagement.

Penelitian ini merupakan penelitian eksplanatori dengan metode pengambilan sampel secara sensus terhadap 60 karyawan generasi Y di PT BPR Restu Artha Makmur Kota Semarang. Teknik pengumpulan data menggunakan kuesioner yang menggunakan skala likert 5 poin. Teknik analisis yang digunakan adalah regresi linear berganda.

Hasil penelitian menunjukkan bahwa: (1) perceived organizational of support berpengaruh positif-signifikan terhadap employee engagement dan negatif-signifikan terhadap turnover intention; (2) leader-member exchange berpengaruh positif-signifikan terhadap employee engagement dan negatifsignifikan terhadap turnover intention; (3) stres kerja berpengaruh negatifsignifikan terhadap employee engagement dan positif-signifikan terhadap turnover intention; (4) employee engagement berpengaruh negatif-signifikan terhadap turnover intention; (5) employee engagement efektif dalam memediasi variabel perceived organizational of support, leader-member exchange, dan stres kerja terhadap turnover intention $(R=0,71$; Sign $=0.00)$.

Kata kunci: perceived organizational of support, leader-member exchange, stres kerja, employee engagement, turnover intention, intervening, Generasi
\end{abstract}




\title{
EFFECT OF PERCEIVED ORGANIZATIONAL OF SUPPORT, LEADER- MEMBER EXCHANGE, AND JOB STRESS ON GENERATION Y TURNOVER INTENTION WITH EMPLOYEE ENGAGEMENT AS INTERVENING VARIABLE
}

\author{
(Case Study On Employees of PT BPR Restu Artha Makmur) \\ Franes Pradusuara; Indarto ${ }^{1)}$; Djoko Santoso $^{2)}$ \\ 1)indarto@usm.ac.id; ${ }^{2)}$ Djoko_hw@usm.ac.id
}

\begin{abstract}
This study aims: (1) To analyze the effect of perceived organizational of support, leader-member exchange, and job stress on employee engagement and turnover intention; (2) To analyze the influence of perceived organizational of support, leader-member exchange, and work stress on Turnover Intention with mediating employee engagement.

This research is explanatory research with census sampling method to 60 $Y$ generation employees at PT BPR Restu Artha Makmur Semarang City. Technique of collecting data using questionnaires using Likert scale 5 points. The analysis technique used is multiple linear regression.

The results showed that: (1) perceived organizational of support positively-significant to employee engagement and negative-significant to turnover intention; (2) leader-member exchange has a significant positive effect on employee engagement and significant negatives to turnover intention; (3) Job Stress has significant effect on employee engagement and positive-significant to turnover intention; (4) employee engagement has a significant negative effect on turnover intention; (5) effective employee engagement in mediating perceived organizational of support, leader-member exchange, and work stress on turnover intention $(R=0.71$; Sign $=0.00)$.

Keywords: perceived organizational of support, leader-member exchange, job stress, employee engagement, turnover intention, intervening, Generation Y.
\end{abstract}




\section{PENDAHULUAN}

Sumber Daya Manusia (SDM) merupakan aset penting dalam perusahaan. Perusahaan akan melakukan usaha terbaiknya demi mendapatkan SDM yang berkualitas. Dimulai dari memasang lowongan kerja diberbagai media massa, melakukan proses seleksi yang ketat, sampai dengan melakukan pengelolaan SDM nya melalui berbagai pelatihan kerja untuk meningkatkan kompetensi sesuai tuntutan jaman. Hal yang berbeda terjadi dalam bidang SDM ketika keberadaan Generasi Y sebagai sebuah angkatan kerja, khususnya dalam industri Perbankan di Indonesia belum mendapat perhatian khusus. Anantatmula (2012) menyarankan pentingnya melihat isu ini dari sisi kesenjangan generasi (generation gap) yang muncul karena kurangnya pemahaman akan keberadaan generasi ini. Dampaknya secara langsung berpengaruh pada kontribusi generasi dalam lingkungan kerja sehingga diperlukan strategi yang sesuai dengan perilaku, nilai dan etika kerja Gen-Y.

Karyawan Generasi Y juga dikenal sebagai generasi yang sering berpindah pindah tempat kerja. Hasil penelitian yang dilakukan sebelumnya, menunjukkan bahwa karyawan Generasi Y akan pindah atau keluar dari pekerjaanya setelah bekerja selama dua tahun. Generasi Y tidak berkeinginan untuk mengorbankan kehidupan untuk bekerja (seperti Generasi sebelumnya). Meskipun begitu Generasi Y dikenal sebagai karyawan yang lebih pintar daripada karyawan yang bekerja keras (Reilly, 2012).

Hubungan keterikatan karyawan dengan perusahaannya bisa dilihat dengan adanya Perceived Organizational of Support (POS). Perceived Organizational of Support adalah tingkatan dimana para karyawan percaya bahwa perusahaan menghargai kontribusi para karyawan dan peduli terhadap masa depan mereka (Robbins, 2013).

Generasi Y, menyukai atasan yang memiliki kedekatan yang baik, teori Leader-Member Exchange terletak pada asumsi bahwa pemimpin mempengaruhi karyawan dalam kelompok mereka (disebut sebagai anggota) melalui kualitas hubungan yang baik, hubungan kualitas tinggi yang ditandai dengan kepercayaan, keinginan, rasa hormat, profesional, dan loyalitas. Leader-Member Exchange merupakan pertukaran sosial antara pemimpin dan anggota yang dapat meliputi sumber daya seperti uang, barang, jasa, status, informasi, dan afiliasi untuk memperoleh hubungan dan dukungan yang baik diantara keduanya.

Generasi Y, memiliki kecenderungan mudah bosan, kurang menyukai halhal rutin. Padahal bisnis perbankan menuntut beberapa pekerjaan rutin untuk setiap harinya dengan aturan yang baku. Tentu hal ini jika dibiarkan akan menyebabkan stres kerja. Dan berujung pada keputusan berpindah tempat kerja. Semuanya dikembalikan kepada perusahaan dan para pemimpin yang peduli dan memperhatikan untuk mengurangi stres karyawan Generasi Y (Cran, 2014).

Jika para karyawan Generasi Y merasa perusahaan cukup memperhatikan mereka, maka mereka akan menunjukkan keterikatan mereka dengan perusahaan yang disebut Employee Engagement. Pengaruh yang biasanya terjadi pada karyawan Generasi Y ketika mereka merasa perusahaan kurang menghargai kontribusinya dan kurang memperhatikan masa depannya, maka para karyawan Generasi Y akan cenderung melakukan Turnover Intention. Turnover Intention 
merupakan keinginan dari seorang karyawan untuk berpindah dari satu organisasi ke organisasi lainnya. Turnover intention memiliki dampak negatif bagi organisasi salah satunya meningkatnya biaya sumber daya manusia.

Tabel 1

Ringkasan Research Gap

\begin{tabular}{|c|c|c|c|}
\hline No & Issue & Penelitian / Tahun & Hasil \\
\hline \multirow[t]{2}{*}{1.} & \multirow{2}{*}{$\begin{array}{lr}\text { Adanya hasil } & \text { penelitian } \\
\text { yang tidak } & \text { konsisten } \\
\text { mengenai } & \text { hubungan } \\
\text { antara } & \text { perceived } \\
\text { organizational } & \text { support } \\
\text { terhadap } & \text { turnover } \\
\text { intention } & \end{array}$} & $\begin{array}{l}\text { 1. Chandra et al. } \\
\text { (2016) }\end{array}$ & $\begin{array}{l}\text { Perceived organizational } \\
\text { support secara parsial dan } \\
\text { simultan memiliki pengaruh } \\
\text { terhadap turnover intention } \\
\text { karyawan }\end{array}$ \\
\hline & & $\begin{array}{l}\text { 2. } \\
\text { Imran et } \\
(2014)\end{array}$ & $\begin{array}{l}\text { Percerived organizational of } \\
\text { support tidak signifikan } \\
\text { mempengaruhi turnover } \\
\text { intention karyawan secara } \\
\text { langsung }\end{array}$ \\
\hline \multirow[t]{2}{*}{2.} & \multirow{2}{*}{$\begin{array}{l}\text { Adanya hasil penelitian } \\
\text { yang tidak konsisten } \\
\text { mengenai } \\
\text { antara leader-member } \\
\text { exchange } \\
\text { turnover intention }\end{array}$} & $\begin{array}{l}\text { 1. Ksama dan I } \\
\text { Made Artha } \\
\text { Wibawa }(2016)\end{array}$ & $\begin{array}{l}\text { Leader-member exchange } \\
\text { berpengaruh negatif dan } \\
\text { signifikan terhadap turnover } \\
\text { intention }\end{array}$ \\
\hline & & $\begin{array}{l}\text { 2. Ozdevecioglu, } \\
\text { et al. (2015) }\end{array}$ & $\begin{array}{l}\text { Leader-member exchange } \\
\text { tidak berpengaruh signifikan } \\
\text { terhadap turnover intention }\end{array}$ \\
\hline \multirow[t]{2}{*}{3.} & \multirow{2}{*}{$\begin{array}{lrr}\text { Adanya hasil } & \text { penelitian } \\
\text { yang tidak } & \text { konsisten } \\
\text { mengenai } & & \text { hubungan } \\
\text { antara } & \text { stress } & \text { kerja } \\
\text { terhadap } & & \text { turnover } \\
\text { intention } & & \end{array}$} & $\begin{array}{l}\text { 1. Adijaya, et al. } \\
\text { (2015) }\end{array}$ & $\begin{array}{l}\text { Terdapat hubungan antara } \\
\text { stress kerja terhadap turnover } \\
\text { intention. }\end{array}$ \\
\hline & & $\begin{array}{l}\text { 2. Tziner, } \\
(2015)\end{array}$ & $\begin{array}{l}\text { Stres kerja tidak berpengaruh } \\
\text { signifikan terhadap turnover } \\
\text { intention }\end{array}$ \\
\hline
\end{tabular}

Sumber : disajikan dari berbagai jurnal

Dalam hal ini ditemukan adanya fenomena dan perbedaan antara beberapa hasil penelitian. Di satu sisi, pihak perusahaan sudah menyediakan fasilitas dan lingkungan kerja yang mendukung untuk meningkatkan produktivitas kerja karyawan, namun di sisi lain turnover karyawan masih tinggi. Berdasarkan uraian tersebut di atas, maka perlu dilakukan kajian hubungan antara perceived organizational of support, gaya kepemimpinan LMX dan stres kerja terhadap turnover intention yang di intervening dengan employee engagement.

\section{Rumusan Masalah Penelitian}

Berdasarkan paparan latar belakang masalah di atas memperlihatkan bahwa permasalahan penelitiannya adalah terjadi fluktuasi turnover karyawan yang cukup tinggi di PT BPR Restu Artha Makmur sehinggga perumusan masalahnya adalah bagaimana menurunkan tingkat turnover dengan mengidentifikasi turnover intention pada PT BPR Restu Artha Makmur. 


\section{TELAAH PUSTAKA DAN PENGEMBANGAN MODEL}

\section{Generasi Y}

Generasi Y merupakan generasi yang lahir pada tahun 1981 hingga 1999 (Reilly, 2012). Saat ini Generasi Y rata-rata berusia antara 16 - 34 tahun yang berarti sebagian besar Generasi Y telah memasuki dunia kerja. Tenaga kerja umur produktif saat ini tercakup dalam tiga tipe Generasi: X, Y dan Baby Boomer (Cran, 2014). Karyawan Generasi Y juga dikenal sebagai generasi yang sering berpindah-pindah tempat kerja. Hasil penelitian yang dilakukan oleh perusahaan Datascript menunjukkan bahwa karyawan Generasi Y akan pindah atau keluar dari pekerjaanya setelah bekerja selama dua tahun (Salam, 2015).

\section{Turnover Intention}

Menurut Fah et al (2010) Keinginan untuk berpindah kerja (turnover intention) merupakan permasalahan yang sangat serius dalam konteks manajemen sumber daya manusia. Turnover intention adalah niat meninggalkan perusahaan secara sukarela, yang dapat mempengaruhi status perusahaan dan dengan pasti akan mempengaruhi produktivitas karyawan.

Beberapa dampak negatif yang akan terjadi pada organisasi akibat pergantian karyawan, seperti : meningkatnya potensi biaya perusahaan, masalah prestasi, masalah pola komunikasi dan sosial, merosotnya semangat kerja, strategi-strategi pengendalian yang kaku, hilangnya biaya-biaya peluang strategik (Manurung dan Ratnawati, 2013).

\section{Employee Engagement}

Employee engagement adalah sebuah filosofi manajemen berdasarkan gagasan yang termasuk atas orang yang tepat didalam keputusan yang tepat pada waktu yang tepat dengan cara yang benar. Dalam hal ini, employee engagement menunjukkan sejauh mana karyawan dapat berguna dalam membuat keputusan di dalam situasi yang krisis (John Smythe, 2007). Menurut Kevin Kruse (2012), employee engagement adalah keadaan dimana seorang karyawan secara emosional berkomitmen terhadap organisasi dan tujuannya. Keterikatan karyawan muncul karena mereka peduli dan bukan hanya karena mereka harus melakukan atau untuk mendapatkan kompensasi ataupun untuk mendapatkan promosi.

\section{Leader Member Exchange}

LMX menjelaskan peran yang yang dibuat antara seorang pemimpin dan bawahan. Ditunjukkan dengan teori yang menguraikan di mana para pemimpin mengembangkan hubungan yang berbeda dengan para bawahan dari waktu ke waktu. Teori LMX menyatakan bahwa suatu hubungan antar pribadi akan meningkat antara supervisor dan para bawahan di dalam suatu lingkungan organisasi formal. Hubungan ini didasarkan pada pertukaran yang "masingmasing pihak harus menawarkan sesuatu, yang pihak lain melihatnya sebagai sesuatu yang berharga dan masing-masing pihak harus melihat pertukaran itu layak atau patut" (Price, 2005). 


\section{Stres Kerja}

Stress kerja didefinisikan sebagai suatu proses yang menyebabkan orang merasa sakit, tidak nyaman atau tegang karena pekerjaannya, tempat kerja atau situasi kerja tertentu. Stres kerja berkaitan dengan bagaimana upaya perusahaan dalam menciptakan suasana kerja yang kondusif. Suasana yang kondusif akan mempengaruhi kinerja karyawan yang juga akan berdampak pada produktifitas. Stres di tempat kerja merupakan hal yang hampir setiap hari dialami oleh para pekerja. Terutama peran di tempat kerja yang semakin beragam dan kadang bertentangan satu sama lain, masalah keluarga dan masih banyak tantangan lainnya yang membuat stress menjadi suatu faktor yang hampir tidak mungkin untuk dihindari. Stres kerja juga dapat disebabkan oleh beban yang tidak diimbangi dengan pemberian waktu yang cukup (Dwi, 2005).

\section{Perceived Organizational of Suport (Persepsi terhadap Dukungan Organisasi)}

Percerived Organizational of Support (POS) adalah tingkatan dimana para karyawan percaya bahwa perusahaan menghargai kontribusi para karyawan dan peduli terhadap masa depan mereka, (Robbins 2013). Senada dengan hal tersebut, Caesens (2014) berpendapat sebuah teori dukungan organisasi atau perceived organizatonal of support disimpulkan dari pendekatan pertukaran sosial untuk menggambarkan hubungan karyawan dan organisasi. Karyawan mengakui dukungan yang mereka peroleh dari organisasi, mereka merasa bahwa mereka memiliki kewajiban untuk itu, dan mengakui perlakuan menguntungkan ini dengan menunjukkan komitmen yang berharga.

\section{Kerangka Pemikiran}

Bank Perkreditan Rakyat (BPR) merupakan lembaga keuangan yang berfungsi menghimpun dana dan menyalurkannya kepada masyarakat dalam pengawasan OJK. Dalam perkembangan bisnisnya, BPR harus mengikuti perkembangan jaman. Salah satunya dalam pengelolaan SDM yang produktif dan profesional.

Generasi Y adalah generasi yang menguasai hampir 50\% dari lapangan pekerjaan saat ini. Disadari atau tidak dengan segala kekurangan dan kelebihannya, generasi Y inilah yang akan diharapkan menjadi pemimpin di masa depan. Dengan karakteristik Gen Y yang mudah sekali berpindah tempat kerja (turnover), maka perusahaan perlu melakukan usaha untuk mengurangi turnover tersebut. Seperti yang telah diketahui, turnover karyawan bisa terjadi karena adanya turnover intentiton dari karyawaan tersebut. Dalam bukunya, Cran (2014) menyatakan bahwa Gen Y tidak termotivasi oleh uang untuk dapat bekerja dengan baik, mereka hanya perlu pengakuan, dukungan perusahaan dan hubungan sosial yang baik. Dengan kata lain, perusahaan akan mendapatkan loyalitas dari Gen Y asalkan minimal tiga hal itu dapat dicukupi oleh perusahaan.

Berdasarkan uraian diatas, maka turnover intentiton dari karyawan Gen Y dipengaruhi oleh usaha-usaha dari perusaan itu sendiri (Perceived Organizational of Support). Dimana jika karyawan merasa ada dukungan dari perusahaan terhadap kesejahteraannya maka keinginan untuk keluar dari perusahaan akan berkurang atau tidak ada sama sekali. Adapun selain hal itu, dengan memiliki 
seorang pemimpin yang selalu memberikan dukungan dan atasan yang selalu melibatkan bawahan dalam hal pengamblan keputusan (Leader Member Exchange), maka karyawan atau bawahan tersebut akan merasa keberadaannya diperusahaan itu penting bagi perusahaan sehingga keinginan untuk keluar dari perusahaan akan berkurang atau tidak ada sama sekali. Selanjutnya apabila karyawan mengalami stress kerja maka turnover bisa benar-benar terjadi. Namun dari itu semua, dengan employee engagement yang kuat diharapkan meminimalisir turnover intention pada karyawan dengan karakteristik Gen Y.

Dengan demikian pola pemikiran dalam penelitian ini digambarkan sebagai berikut:

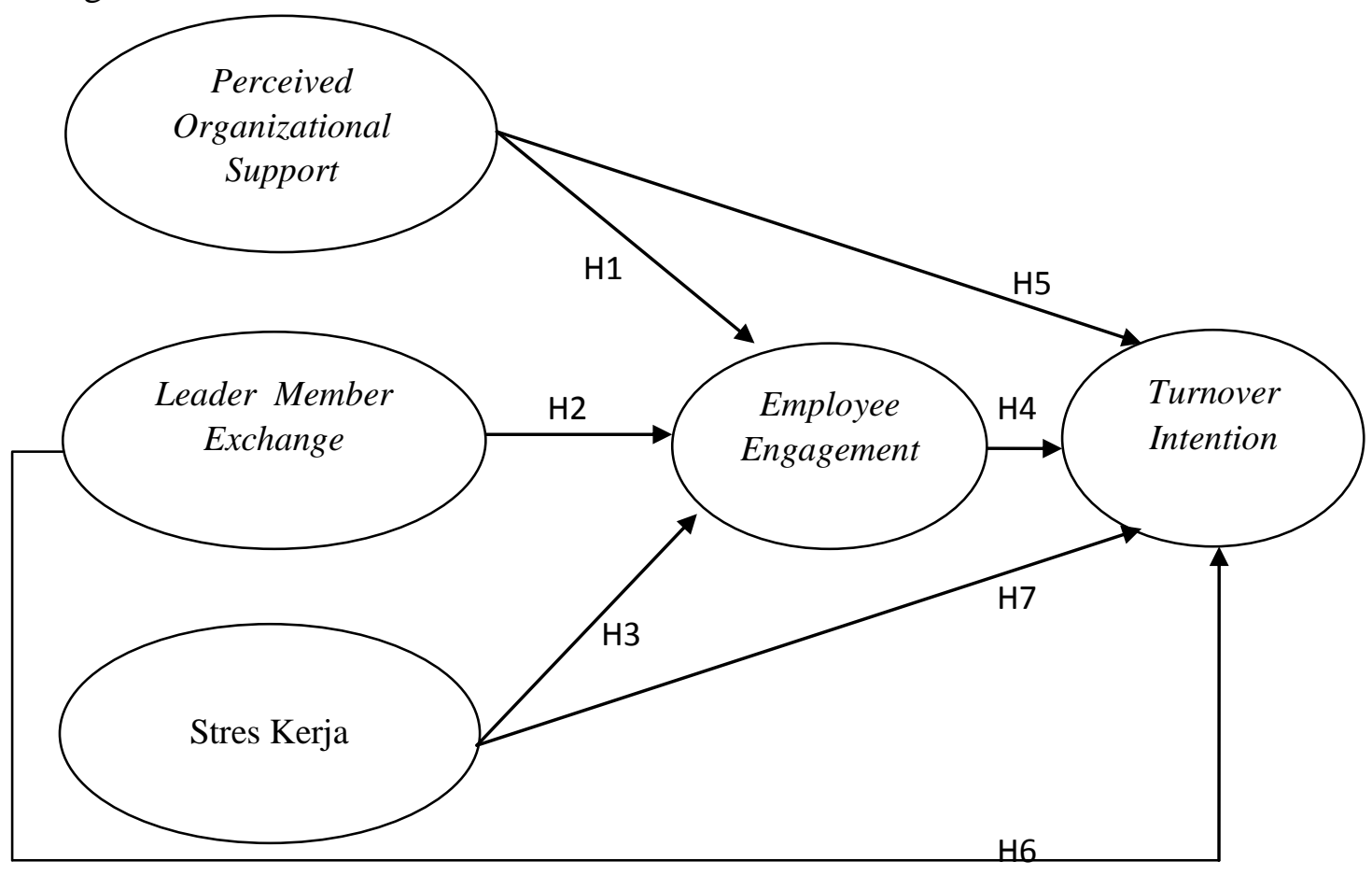

Gambar 1 : Kerangka Pemikiran

\section{METODE PENELITIAN}

\section{Populasi dan Sampel}

Jenis penelitian ini adalah penelitian eksplanatori (Explanatory Research). Sebuah penelitian eksplanatori menurut Ferdinand (2006) merupakan penelitian yang menjelaskan hubungan kausal antara variabel penelitian dengan pengujian hipotesa. Di dalam penelitian eksplanatori, pendekatan yang dipakai dalam penelitian ini adalah metode survei, yaitu penelitian yang dilakukan untuk memperoleh fakta-fakta mengenai fenomena-fenomena yang ada di dalam obyek penelitian dan mencari keterangan secara aktual dan sistematis.

Populasi dari penelitian ini adalah seluruh karyawan yang ada di PT BPR Restu Artha Makmur yang termasuk dalam kategori Gen Y (tahun kelahiran 1984 - 1995 ) yaitu sejumlah 60 orang yang diambil secara sensus 


\section{Metode Pengumpulan data}

Metode pengumpulan data dalam penelitian ini akan dilakukan dengan cara pembagian kuesioner. Kuesioner merupakan teknik pengumpulan data yang dilakukan dengan cara memberi seperangkat pertanyaan atau pernyataan tertulis kepada responden untuk dijawabnya (Sugiono, 2008). Pertanyaan dalam kuesioner diuji dengan menggunakan skala likert 1-5, hal ini untuk mendapatkan data yang bersifat internal dan di beri skor.

\section{Pengujian Hipotesis}

Data yang telah terdistribusi normal, di uji menggunakan metode regresi linear berganda ini dikembangkan untuk menguji pengaruh lebih dari satu variabel independen $(\mathrm{X})$ terhadap satu variabel dependen (Y). Adapun bentuk persamaan regresi adalah sebagai berikut:

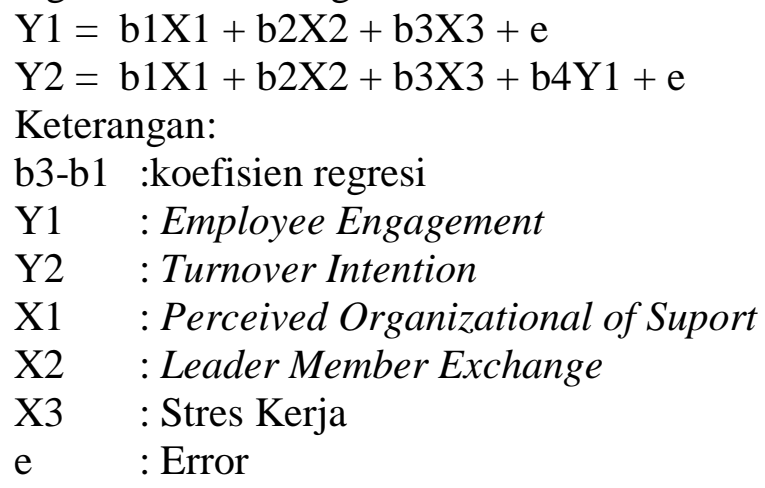

Uji t digunakan untuk mengetahui dan membuktikan apakah ada pengaruh antara variabel-variabel bebas terhadap variabel terikat secara parsial pada $\alpha=$ 0,05 . Adapun kriteria hasil pengujian menunjukan:

$\mathrm{H} 0$ diterima jika nilai Sig $\mathrm{t}>0,05$.

$\mathrm{H} 0$ ditolak jika nilai Sig $\mathrm{t}<0,05$.

Analisis regresi dengan intervening digunakan untuk mengetahui total pengaruh variabel independen terhadap variabel dependen yang terdiri dari pengaruh langsung dan pengaruh tidak langsung, yakni melalui variabel intervening. Untuk mengetahui pengaruh tidak langsung termasuk kategori pengaruh langsung variabel employee engagement mampu menjadi variabel intervening, maka dilakukan uji efek mediasi dengan membandingkan hasil koefisien standardize secara langsung dan tidak langsung, dikatakan mampu memediasi jika pengaruh tidak langsung lebih besar dari pengaruh langsung (Ghozali, 2011). 


\section{Definisi Operasional Variabel dan Indikator}

Tabel 2

Definisi Operasional dan Indikator Variabel Penelitian

\begin{tabular}{|c|c|c|c|}
\hline & Variabel & Definisi Operasional & Indikator \\
\hline $\mathrm{X} 1$ & $\begin{array}{l}\text { Perceived } \\
\text { Organizational } \\
\text { Support }\end{array}$ & \begin{tabular}{lrr} 
Persepsi & umum & karyawan \\
mengenai & sejauh & mana \\
perusahaan & \multicolumn{2}{c}{ menghargai } \\
kontribusi & karyawan serta \\
seberapa besar dukungan \\
perusahaan terhadap pekerjaan \\
karyawan dan kesejahteraan \\
karyawan yang bersangkutan.
\end{tabular} & 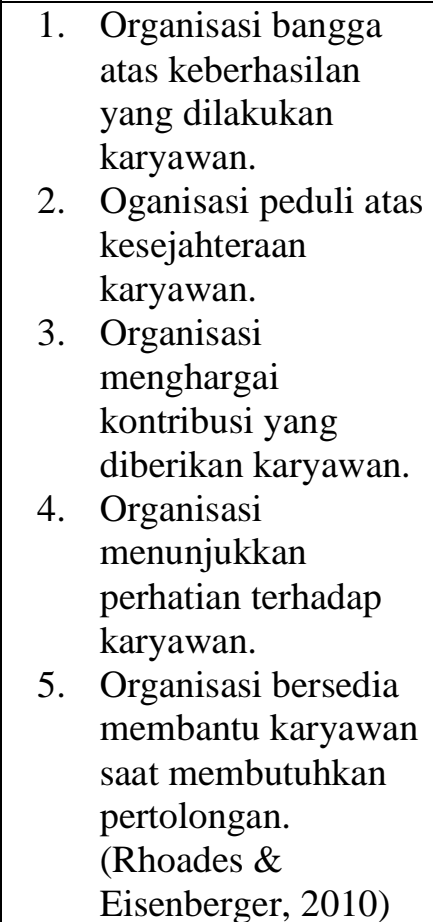 \\
\hline $\mathrm{X} 2$ & $\begin{array}{l}\text { Leader Member } \\
\text { Exchange }\end{array}$ & $\begin{array}{l}\text { sejauh mana pemimpin dan } \\
\text { bawahan saling tukar sumber } \\
\text { daya dan dukungan, merupakan } \\
\text { pertukaran sosial antara } \\
\text { pemimpin dan anggota yang } \\
\text { dapat meliputi Sumber daya } \\
\text { seperti uang, barang, jasa, status, } \\
\text { informasi, dan afiliasi untuk } \\
\text { memperoleh hubungan dan } \\
\text { dukungan yang baik diantara } \\
\text { keduanya. }\end{array}$ & $\begin{array}{l}\text { 1. } \text { Tanggapan terhadap } \\
\text { bantuan atasan } \\
\text { 2. Tanggapan terhadap } \\
\text { atasan dan cara } \\
\text { pandangnya terhadap } \\
\text { potensi } \\
\text { 3. Penghormatan atasan } \\
\text { 4. Percaya terhadap } \\
\text { atasannya } \\
\text { (Chaurasia, 2013) }\end{array}$ \\
\hline X3 & Stres Kerja & $\begin{array}{l}\text { Stres adalah kondisi dinamik } \\
\text { yang di dalamnya individu } \\
\text { menghadapi } \\
\text { kendalaatau tuntutan yang } \\
\text { terkait dengan apa yang sangat } \\
\text { diinginkannya dan yang hasilnya } \\
\text { dipersepsikan sebagai tidak pasti } \\
\text { tetapi penting. }\end{array}$ & $\begin{array}{l}\text { 1. } \text { Emosi tidak stabil, } \\
\text { 2. Suka menyendiri, } \\
\text { 3. Sulit tidur, } \\
\text { 4. Tidak bisa rileks, } \\
\text { 5. Tegang, } \\
\text { (Mangkunegara, 2005) }\end{array}$ \\
\hline Y1 & $\begin{array}{l}\text { Employee } \\
\text { Engagement }\end{array}$ & $\begin{array}{l}\text { Employee engagement } \\
\text { merupakan keadaan dimana } \\
\text { anggota dari organisasi } \\
\text { mengidentifikasi dirinya dengan } \\
\text { pekerjaannya, mengekspresikan }\end{array}$ & $\begin{array}{l}\text { 1. Siap mendedikasikan } \\
\text { diri pada pekerjaan } \\
\text { 2. } \begin{array}{l}\text { Semangat dalam } \\
\text { melaksanakan } \\
\text { pekerjaan }\end{array}\end{array}$ \\
\hline
\end{tabular}




\begin{tabular}{|c|c|c|c|}
\hline & & $\begin{array}{l}\text { diri mereka secara fisik, kognitif } \\
\text { dan emosional selama } \\
\text { menunjukkan kinerja mereka. }\end{array}$ & $\begin{array}{l}\text { 3. Kesediaan memotivasi } \\
\text { diri untuk mencapai } \\
\text { keberhasilan } \\
\text { 4. Kesediaan untuk } \\
\text { bekerja keras atau } \\
\text { bekerja ekstra keras } \\
\text { 5. Pekerjaan dikerjakan } \\
\text { secara menyeluruh } \\
\text { (Chandra, 2016) }\end{array}$ \\
\hline Y2 & $\begin{array}{l}\text { Turnover } \\
\text { Intention }\end{array}$ & $\begin{array}{l}\text { Turnover intentionmerupakan } \\
\text { suatu keadaan dimana pekerja } \\
\text { memiliki niat atau kecendrungan } \\
\text { yang dilakukan secara sadar } \\
\text { untuk mencari suatu pekerjaan } \\
\text { lain sebagai alternatif di } \\
\text { organisasi yang berbeda dan } \\
\text { turnover adalah pergerakan } \\
\text { keluarnya tenaga kerja dari } \\
\text { tempatnya bekerja. }\end{array}$ & $\begin{array}{l}\text { 1. Niat untuk keluar, } \\
\text { 2. mulai malas kerja, } \\
\text { 3. memikirkan untuk } \\
\text { keluar } \\
\text { 4. mencari pekerjaan lain } \\
\text { 5. absensi yang meningkat } \\
\text { (Chandra, 2016) }\end{array}$ \\
\hline
\end{tabular}

\section{HASIL DAN PEMBAHASAN}

\section{Pengujian Regresi}

Dalam pengujian regresi linier berganda ini terdapat dua model yaitu pengaruh tidak langsung dan pengaruh langsung. Persamaan regresi pengaruh perceived organizational of support, leader member exchange dan stres kerja terhadap employee engagement.

\section{Tabel 3}

\section{Hasil Uji Regresi Model 1}

\section{Coefficients $^{\mathbf{a}}$}

\begin{tabular}{|c|c|c|c|c|c|c|}
\hline \multirow{2}{*}{\multicolumn{2}{|c|}{ Model }} & \multicolumn{2}{|c|}{$\begin{array}{c}\text { Unstandardized } \\
\text { Coefficients }\end{array}$} & \multirow{2}{*}{$\begin{array}{c}\begin{array}{c}\text { Standardized } \\
\text { Coefficients }\end{array} \\
\text { Beta } \\
\end{array}$} & \multirow[b]{2}{*}{$t$} & \multirow[b]{2}{*}{ Sig. } \\
\hline & & B & Std. Error & & & \\
\hline \multirow[t]{4}{*}{1} & (Constant) & 17.933 & 1.361 & & 13.173 & .000 \\
\hline & $\begin{array}{l}\text { Perceived Organizational } \\
\text { of Support }\end{array}$ & .348 & .039 & .865 & 8.976 & .000 \\
\hline & $\begin{array}{l}\text { Leader Member } \\
\text { Exchange }\end{array}$ & .392 & .095 & 478 & 4.145 & .000 \\
\hline & Stres Kerja & -.415 & .111 & -.497 & -3.743 & .000 \\
\hline
\end{tabular}

Dependent Variable: Employee Engagement

Sumber : Data Primer yang diolah 2017

Pada persamaan regresi pada tabel 4 dinyatakan dalam standardized coefisients dengan pertimbangan bahwa ukuran variabel bersifat kualitatif atau 
abstrak (Ghozali, 2011), sehinggga dapat dinyatakan dengan persamaan sebagai berikut :

$$
Y_{1}=0,865 X 1+0,478 X 2-0,497 X 3
$$

Keterangan:

$\mathrm{Y}_{1}$ : Variabel Employee Engagement

X1 : Variabel Perceived Organizational of Support

X2: Variabel Leader Member Exchange

X3 : Variabel Stres Kerja

Persamaan regresi tersebut di atas dapat dijelaskan sebagai berikut :

a. Nilai koefisien regresi perceived organizational of support terhadap employee engagement menunjukkan nilai parameter positif sebesar 0,865 dapat diartikan bahwa perceived organizational of support dapat menumbuhkan rasa employee engagement.

b. Nilai koefisien regresi leader member exchange terhadap employee engagement menunjukkan nilai parameter positif sebesar 0,478 dapat diartikan bahwa leader member exchange dapat menumbuhkan rasa employee engagement.

c. Nilai koefisien regresi stres kerja terhadap employee engagement menunjukkan nilai parameter negatif sebesar - 0,497 dapat diartikan bahwa stres kerja mengurangi rasa employee engagement.

1. Persamaan regresi pengaruh perceived organizational of support, leader member exchange, stress kerja dan employee engagement terhadap turnover intention

Tabel 4

Hasil Uji Regresi Model 2

Coefficients $^{\mathrm{a}}$

\begin{tabular}{|c|c|c|c|c|c|c|}
\hline \multirow[b]{2}{*}{ Mode } & & \multicolumn{2}{|c|}{$\begin{array}{c}\text { Unstandardized } \\
\text { Coefficients } \\
\end{array}$} & \multirow{2}{*}{$\begin{array}{c}\begin{array}{c}\text { Standardized } \\
\text { Coefficients }\end{array} \\
\text { Beta }\end{array}$} & \multirow[b]{2}{*}{$t$} & \multirow[b]{2}{*}{ Sig. } \\
\hline & & B & $\begin{array}{l}\text { Std. } \\
\text { Error }\end{array}$ & & & \\
\hline \multirow[t]{5}{*}{1} & (Constant) & 1.448 & 1.463 & & .990 & .327 \\
\hline & $\begin{array}{l}\text { Perceived Organizational } \\
\text { of Support }\end{array}$ & -.099 & .032 & -.207 & -3.082 & .00 \\
\hline & $\begin{array}{l}\text { Leader Member } \\
\text { Exchange }\end{array}$ & -.683 & .057 & -.706 & -13.647 & .0 \\
\hline & Stres Kerja & .215 & .066 & .217 & 3.262 & .002 \\
\hline & Employee Engagement & -.084 & .071 & -.155 & -2.589 & .012 \\
\hline
\end{tabular}

a. Dependent Variable: Turnover Intention

Sumber : Data primer yang diolah, 2017 
Persamaan regresinya adalah sebagai berikut:

$$
\mathrm{Y}_{2}=-0,207 \mathrm{X} 1-0,706 \mathrm{X} 2+0,217 \mathrm{X} 3-0,155 \mathrm{Y} 1
$$

Keterangan:

$\mathrm{Y}_{1}$ : Variabel Employee Engagement

$\mathrm{Y}_{2}$ : Variabel Turnover Intention

X1 : Variabel Perceived Organizational of Support

X2 : Variabel Leader Member Exchange

X3 : Variabel Stres Kerja

Dari persamaan regresi linier berganda tersebut diatas menunjukkan bahwa :

a. Nilai koefisien regresi perceived organizational of support terhadap turnover intention menunjukkan nilai parameter negatif sebesar - 0,207 dapat diartikan bahwa perceived organizational of support dapat mengurangi niat untuk pindah seorang karyawan.

b. Nilai koefisien regresi leader member exchange terhadap turnover intention menunjukkan nilai parameter negatif sebesar - 0,706 dapat diartikan bahwa leader member exchange dapat mengurangi niat untuk pindah seorang karyawan.

c. Nilai koefisien regresi stres kerja terhadap turnover intention menunjukkan nilai parameter positif sebesar 0,217 dapat diartikan bahwa stress kerja dapat meningkatkan niat untuk pindah seorang karyawan.

d. Nilai koefisien regresi employee engagement terhadap turnover intention menunjukkan nilai parameter negatif sebesar - 0,155 dapat diartikan bahwa employee engagement dapat mengurangi niat untuk pindah seorang karyawan.

\section{Uji Hipotesis (Uji t)}

a. Hipotesis 1 : Perceived Organizational Of Support Berpengaruh Positif Terhadap Employee Engagement

Hasil pengujian hipotesis antara perceived organizational of support terhadap employee engagement diperoleh nilai signifikansi sebesar 0,000 $<0,05$ dan nilai $\mathrm{t}$ sebesar 8,976 . Penjelasan tersebut dapat diartikan bahwa perceived organizational of support berpengaruh positif terhadp employee engagement. Dan dapat disimpulkan H1 Diterima,artinya keberhasilan, kesejahteraan kontribusi perhatian dan bantuan karyawan merupakan indikator dari variabel perceived organizational of support yang dijadikan pertanyaan dalam kuesioner yang disebar kepada responden, menunjukkan hubungan yang positif dan signifikan terhadap employee engagement. Mengandung maksud semakin baik perceived organizational of support akan semakin tinggi rasa employee engagement.

Perceived organizational of support sangat erat kaitannya dengan keterikatan karyawan dikarenakan dengan adanya dukungan organisasi karyawan merasa dihargai oleh perusahaan, Caesens (2014) berpendapat sebuah teori dukungan organisasi atau percevied organiasional of support disimpulkan dari pendekatan pertukaran sosial untuk menggambarkan hubungan karyawan dan organisasi. Karyawan mengakui dukungan yang mereka peroleh dari organisasi, mereka merasa bahwa mereka memiliki kewajiban untuk itu, dan mengakui perlakuan 
menguntungkan ini dengan menunjukkan komitmen yang berharga. Hasil penelitian ini juga sesuai dengan hasil penelitian oleh Alvi et al (2014) dimana percevied organiasional of support sangat mempengaruhi employee engagement

b. Hipotesis 2 : Leader Member Exchange Berpengaruh Positif Terhadap Employee Engagement

Hasil pengujian hipotesis antara leader member exchange terhadap employee engagement diperoleh nilai signifikansi sebesar $0,000<0,05$ dan nilai $\mathrm{t}$ sebesar 4,145. Penjelasan tersebut dapat diartikan bahwa leader member exchange berpengaruh positif terhadap employee engagement, dan dapat disimpulkan $\mathbf{H 2}$ Diterima artinya bantuan cara pandang, penghormatan, dan kepercayaan atasan merupakan indikator dari variabel leader member exchange yang dijadikan pertanyaan dalam kuesioner yang disebar kepada responden, menunjukkan hubungan yang positif dan signifikan terhadap employee engagement. Mengandung maksud semakin baik leader member exchange akan semakin tinggi rasa employee engagement.

Tingkat kedekatan dari hubungan antara pimpinan dan bawahan ini yang menunjukkan adanya indikasi dari leader member exchange di perusahaan dalam sebuah organisasi, dimungkinkan terdapat hubungan yang berbeda antara pimpinan dengan karyawan yang menjadi anak buahnya. Senada dengan hal tersebut Morrow et al. (dalam Collins 2007) menyatakan bahwa leader member exchange merupakan tingkat kualitas hubungan antara supervisi dengan karyawan yang mampu meningkatkan kinerja keduanya. Hasil penelitian ini juga sesuai dengan hasil penelitian oleh Chaurasia dan Archana (2013) dimana leader member exchange sangat mempengaruhi employee engagement.

\section{c. Hipotesis 3 : Stres Kerja Berpengaruh Negatif Terhadap Employee Engagement}

Hasil pengujian hipotesis antara stress kerja terhadap employee engagement diperoleh nilai signifikansi sebesar $0,000<0,05$ dan nilai t sebesar $\quad-3,743$. Penjelasan tersebut dapat diartikan bahwa stres kerja berpengaruh negatif terhadap employee engagement sehingga $\mathbf{H 3}$ Diterima artinya indikator emosi tidak stabil, suka menyendiri, sulit tidur, tidak bisa rileks dan tegang merupakan indikator dari variabel stres kerja yang dijadikan pertanyaan dalam kuesioner yang disebar kepada responden, menunjukkan hubungan yang negatif dan signifikan terhadap employee engagement. Mengandung maksud semakin tinggi tingkat stres kerja karyawan maka semakin rendah rasa employee engagement yang dimiliki.

Stres kerja berdampak negatif terhadap employee engagement, dimana semakin tinggi tingkat stress kerja karyawan maka employee engagementnya semakin menurun (Endah dan Sito, 2014). Menurut Mangkunegara (2009) stres karyawan sangat mempengaruhi emosi yang tidak stabil sehingga mengakibatkan engagement karyawan berkurang. Stres yang dialami karyawan akan membawa dampak yang negatif terhadap perusahaan sehingga menghambat kinerja. Didorong dengan adanya engagement antar karyawan dinilai bisa mengantisipasi 
rasa stres yang ada. Hasil penelitian ini juga sesuai dengan hasil penelitian oleh Endah dan Sito (2014) dimana stres kerja sangat mempengaruhi employee engagement.

\section{d. Hipotesis 4 : Employee Engagement Berpengaruh Negatif Terhadap Turnover Intention}

Hasil pengujian hipotesis antara employee engagement terhadap turnover intention diperoleh nilai signifikansi sebesar 0,012 <0,05 dan nilai t sebesar - 2,589. Penjelasan tersebut dapat diartikan employee engagement berpengaruh negatif terhadap turnover intention, sehingga H4 Diterima artiny indikator siap mendedikasikaan diri pada pekerjaan, semangat bekerja, memotivasi diri,bekerja keras, dan bekerja secara lengkap dan menyeluruh merupakan indikator dari variabel employee engagement yang dijadikan pertanyaan dalam kuesioner yang disebar kepada responden, menunjukkan hubungan yang negatif dan signifikan terhadap employee engagement. Mengandung maksud semakin tinggi rasa employee engagement semakin menurun tingkat turnover intention karyawan. Hasil penelitian ini juga sesuai dengan hasil penelitian oleh Deborah et al (2015) dimana employee engagement sangat mempengaruhi turnover intention.

Karyawan yang engaged menghasilkan pekerjaan yang lebih produktif, lebih menguntungkan, lebih aman, lebih sehat, memiliki kecenderungan turnover yang rendah, tingkat absen yang minim, dan memiliki keinginan yang lebih kuat untuk memberikan usaha maksimal dalam pekerjaannya (Chandra et al, 2016). Dengan adanya keterikatan karyawan dengan perusahaan maka diharapkan karyawan akan peduli terhadap perusahaan sehingga menurunkankan tingkat turnover intention.

e. Hipotesis 5 : Perceived Organizational Of Support Berpengaruh Negatif Terhadap Turnover Intention

Hasil pengujian hipotesis antara perceived organizational of support terhadap turnover intention diperoleh nilai signifikansi sebesar 0,003 $<0,05$ dan nilai $t$ sebesar -3,082. Penjelasan tersebut dapat diartikan perceived organizational of support berpengaruh negatif terhadap turnover intention dan dapat disimpulkan bahwa H5 Diterima. Yang berarti bahwa semakin tinggi perceived organizational of support yang ada maka dapat menurunkan tingkat turnover intention dan begitu juga sebaliknya apabila perceived organizational of support yang dilakukan oleh perusahaan rendah maka tingkat turnover intention akan meningkat. Hasil penelitian ini juga sesuai dengan hasil penelitian oleh Chandra et al (2016) dimana perceived organizational of support memiliki pengaruh terhadap turnover intention

Hal ini berarti bahwa perceived organizational of support mempunyai andil untuk menurunkan tingkat turnover intention karyawan yang ada. Dukungan organisasi yang didasarkan oleh karyawan dan apabila dukungan itu cocok dengan nilai norma, harapan dan keinginannya maka karyawan dengan sendirinya akan memiliki komitmen dalam memenuhi kewajiban organisasi. Dengan Perceived Organizatonal of Support maka karyawan tidak akan pernah meninggalkan 
organisasi, karna karyawan merasa bahwa dirinya memiliki ikatan yang kuat dengan organisasi dimana dia bekerja (Eisenberger et al., 2002).

\section{Pengaruh Leader Member Exchange Terhadap Turnover Inte}

\section{f. Hipotesis 6 : Leader Member Exchange Berpengaruh Negatif Terhadap} Turnover Intention

Hasil pengujian hipotesis antara leader member exchange terhadap turnover intention diperoleh nilai signifikansi sebesar $0,000<0,05$ dan nilai $\mathrm{t}$ sebesar - 13,647. Penjelasan tersebut dapat diartikan leader member exchange berpengaruh negatif terhadap turnover intention, sehingga dapat disimpulkan bahwa H6 Diterima. Yang berarti bahwa leader member exchange dapat membuat karyawan merasa nyaman sehingga tidak ada niat untuk pindah bekerja ditempat yang lain. Semakin leader member exchange tinggi maka akan menurunkan tingkat turnover intention karyawan, begitu juga sebaliknya. Hasil penelitian ini juga sesuai dengan hasil penelitian oleh Ksama (2016) dimana leader member exchange memiliki pengaruh negatif terhadap turnover intention.

Leader member exchange menjelaskan peran yang yang dibuat antara seorang pemimpin dan bawahan. Ditunjukkan dengan teori yang menguraikan di mana para pemimpin mengembangkan hubungan yang berbeda dengan para bawahan dari waktu ke waktu. Teori LMX menyatakan bahwa suatu hubungan antar pribadi akan meningkat antara supervisor dan para bawahan di dalam suatu lingkungan organisasi formal. Hubungan ini didasarkan pada pertukaran yang masing-masing pihak harus menawarkan sesuatu, yang pihak lain melihatnya sebagai sesuatu yang berharga dan masing-masing pihak harus melihat pertukaran itu layak atau patut (Price, 2005). Dan apabila hubungan antara atasan dan bawahan kurang harmonis maka bisa terjadi turnover intention.)

g. Hipotesis 7 : Stres Kerja Berpengaruh Positif Terhadap Turnover Intention Hasil pengujian hipotesis antara stress kerja terhadap turnover intention diperoleh nilai signifikansi sebesar $0,002<0,05$ dan nilai t sebesar 3,262. Penjelasan tersebut dapat diartikan stress kerja berpengaruh positif terhadap turnover intention, dan dapat diartikan bahwa $\mathbf{H} 7$ Diterima. Yang berarti bahwa apabila stres kerja semakin tinggi maka turnover intention juga semakin tinggi, begitu juga sebaliknya apabila stres kerja menurun maka turnover intention juga akan ikut menurun. Stres kerja yang dirasakan karyawan akan membuat pikirannya tidak dapat berfikir secara tenang dan positif, orang yang mengalami stres kerja akan mengganggu dalam bekerja secara individu ataupun tim. Sehingga tingkat stres karyawan perlu diperhatikan untuk mengantisipasi turnover intention. Hasil penelitian ini juga sesuai dengan hasil penelitian oleh Johartono dan Retnaningtyas (2013) dimana stres kerja memiliki pengaruh positif terhadap turnover intention

Sejalan dengan Mangkunegara (2009) menyatakan bahwa stres kerja adalah perasaan tertekan yang dialami karyawan dalam menghadapi pekerjaan. Stres kerja yang meningkat akan berpengaruh pada meningkatnya turnover intention. Dengan adanya turnover yang tinggi maka perusahaan harus mengeluarkan biaya yang tinggi pula untuk mengadakan perekrutan karyawan kembali. Oleh sebab 
itu perusahaan dituntut untuk membuat nyaman karyawannya. Dengan adanya kenyamanan di lingkungan kerja dinilai dapat mengurangi rasa stres. Dan dengan berkurangnya stres kerja maka diharapkan berkurangnya turnover intention.

\section{Uji Model (Uji F)}

Uji F dilakukan untuk menguji kelayakan model regresi linier berganda. Kriteria pengujian dengan uji $\mathrm{F}$ adalah dengan membandingkan taraf signifikansi dari nilai $\mathrm{F}(\alpha=0,05)$. Nilai $\mathrm{F}$ hitung sebesar 35,636 dan signifikansi sebesar $0,000<0,005$ dapat diartikan bahwa model regresi dalam penelitian ini dapat dikatakan fit atau baik, sehingga dapat digunakan untuk memprediksi penelitian yang akan datang. Nilai F hitung sebesar 189,66 dan signifikansi sebesar 0,000 < 0,05 dapat diartikan bahwa model regresi dalam penelitian ini dapat dikatakan fit atau baik, sehingga dapat digunakan untuk memprediksi penelitian yang akan datang.

\section{Uji Intervening}

Untuk mengetahui pengaruh tidak langsung termasuk kategori pengaruh langsung variabel employee engagement mampu menjadi variabel intervening, maka dilakukan uji efek mediasi dengan membandingkan hasil koefisien standardize secara langsung dan tidak langsung. Berikut masing-masing hasil pengujian mediasi pengaruh langsung dan tidak langsung :

1. Perceived organizational of support terhadap turnover intention dengan employee engagement sebagai variabel intervening

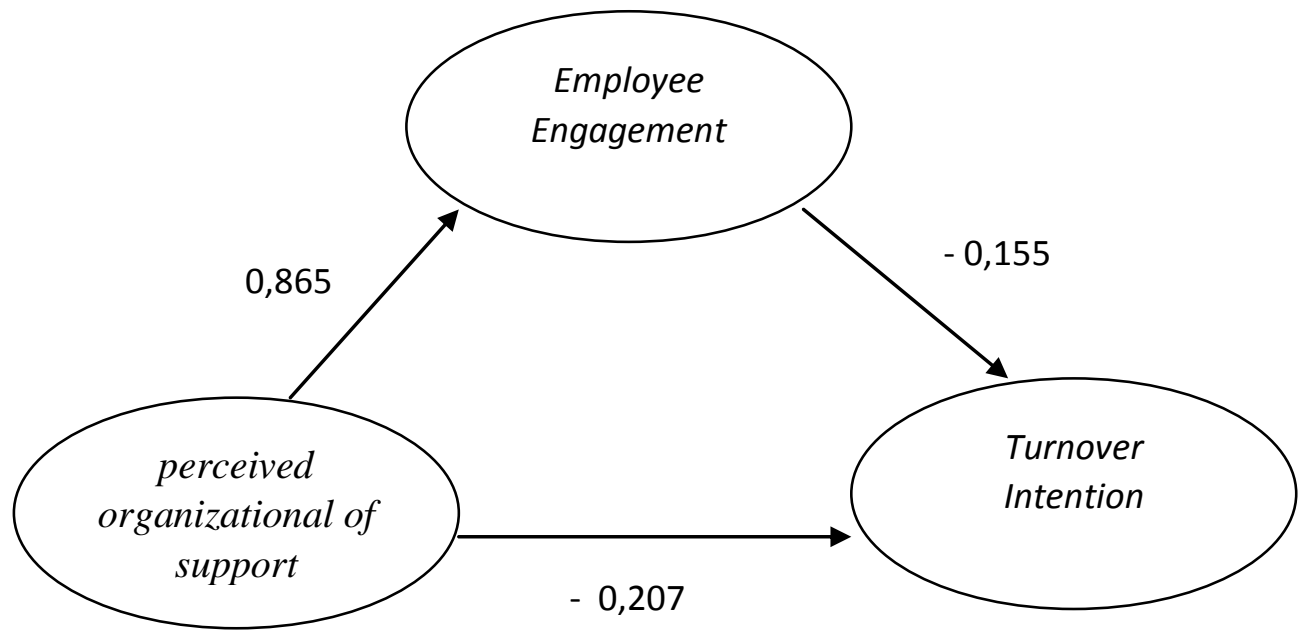

Gambar 2 : Uji Intervening 1

Dari gambar di atas dapat dilihat bahwa :

a. Pengaruh langsung antara perceived organizational of support terhadap turnover intention adalah sebesar $=-0,207$

b. Pengaruh tidak langsung antara perceived organizational of support terhadap turnover intention dengan employee engagement sebagai variabel intervening sebesar $0,865 \mathrm{x}-0,155=-1,34$ 
Sehingga dapat disimpulkan bahwa - 1,34> - 0,207, yang berarti bahwa variabel employee engagement efektif dalam memediasi variabel perceived organizational of support terhadap turnover intention

2. Pengaruh Pengaruh leader member exchange terhadap turnover intention dengan employee engagement sebagai variabel intervening

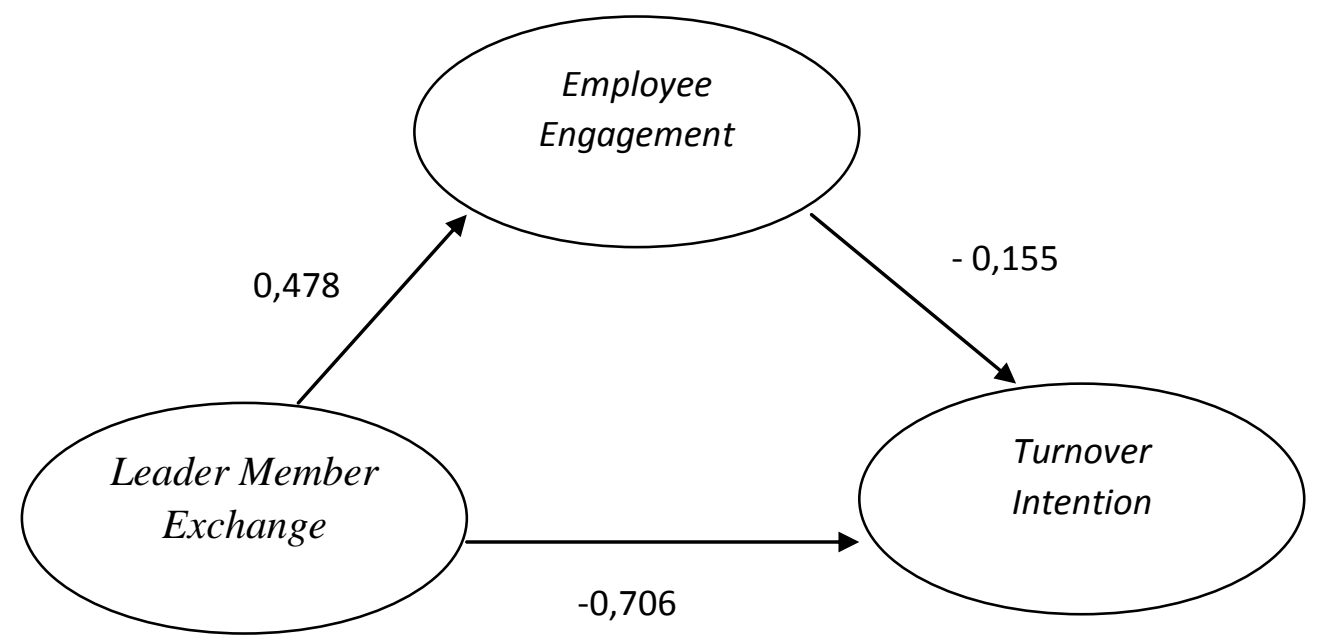

Gambar 3 : Uji Intervening 2

Dari gambar di atas dapat dilihat bahwa :

a. Pengaruh langsung antara leader member exchange terhadap turnover intention adalah sebesar $=-0,706$

b. Pengaruh tidak langsung antara leader member exchange terhadap turnover intention dengan employee engagement sebagai variabel intervening sebesar $\quad 0,478 \mathrm{x}-0,155=-0,740$

Sehingga dapat disimpulkan bahwa $-0,740>-0,706$ yang berarti bahwa variabel employee engagement efektif dalam memediasi variabel kepuasan kerja terhadap turnover intention.

3. Pengaruh stres kerja terhadap turnover intention dengan employee engagement sebagai variabel intervening

Dari gambar di bawah, dapat dilihat bahwa :

a. Pengaruh langsung antara stres kerja terhadap turnover intention adalah sebesar $=0,217$

b. Pengaruh tidak langsung antara stres kerja terhadap turnover intention dengan employee engagement sebagai variabel intervening sebesar $-0,497 \mathrm{x}-0,155=0,770$

Sehingga dapat disimpulkan bahwa $0,770>0,217$, yang berarti bahwa variabel employee engagement efektif dalam memediasi variabel stres kerja terhadap turnover intention. 


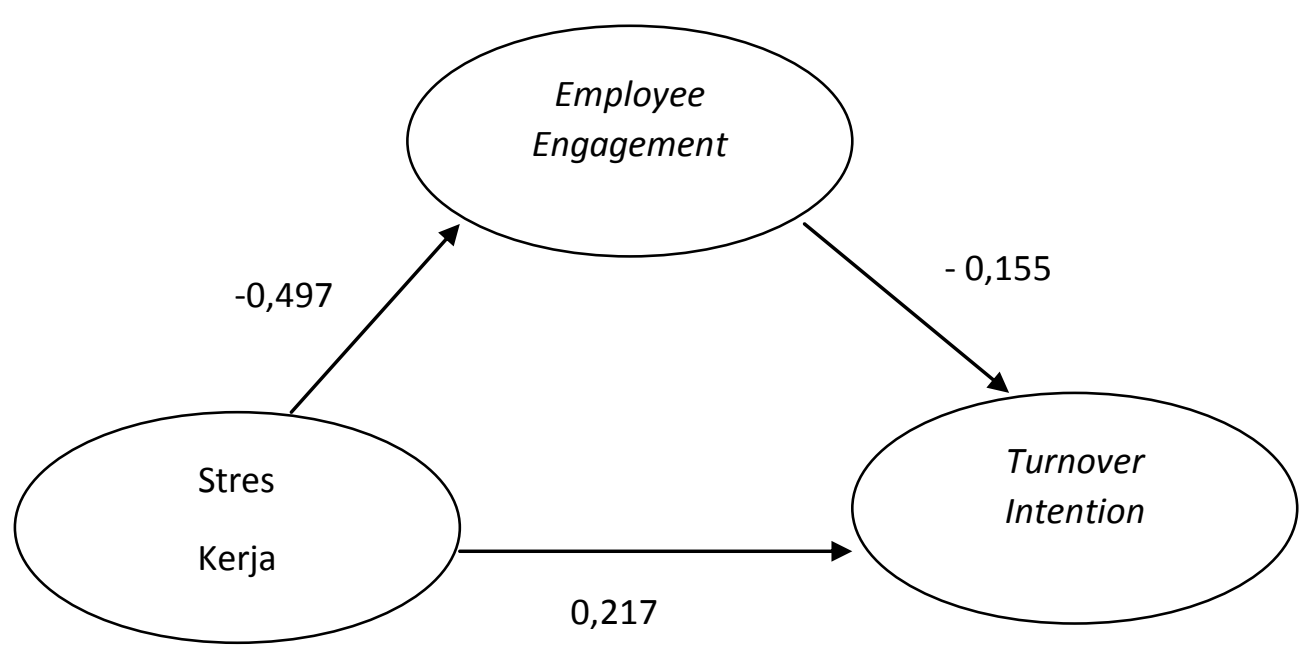

Gambar 4 : Uji Intervening 3

Dari gambar di atas, dapat dilihat bahwa :

a. Pengaruh langsung antara stres kerja terhadap turnover intention adalah sebesar $=0,217$

b. Pengaruh tidak langsung antara stres kerja terhadap turnover intention dengan employee engagement sebagai variabel intervening sebesar $-0,497 \mathrm{x}-0,155=0,770$

Sehingga dapat disimpulkan bahwa $0,770>0,217$, yang berarti bahwa variabel employee engagement efektif dalam memediasi variabel stres kerja terhadap turnover intention.

\section{PENUTUP}

\section{Kesimpulan}

Berdasarkan hasil penelitian dan pembahasan yang telah disampaikan pada bab sebelumnya, maka dapat diambil kesimpulan sebagai berikut:

1. Perceived organizational of support berpengaruh positif terhadap employee engagement. Maknanya adalah dengan meningkatnya Perceived organizational of support yang dimiliki oleh karyawan, maka semakin tinggi employee engagement dari kayawan tersebut.

2. Leader member exchange berpengaruh positif terhadap employee engagement. Maknanya adalah dengan meningkatnya leader member exchange yang dimiliki oleh karyawan, maka semakin tinggi employee engagement dari kayawan tersebut.

3. Stres kerja berpengaruh negatif terhadap employee engagement. Maknanya adalah dengan meningkatnya stres kerja yang dirasakan karyawan, maka akan menurunkan employee engagement dari kayawan tersebut.

4. Perceived organizational of support berpengaruh negatif terhadap turnover intention. Maknanya adalah dengan meningkatnya perceived 
organizational of support yang dimiliki oleh karyawan, maka akan menurunkan turnover intention dari karyawan tersebut.

5. Leader member exchange berpengaruh negatif terhadap turnover intention. Maknanya adalah dengan meningkatnya leader member exchange yang dimiliki oleh karyawan, maka akan menurunkan turnover intention dari karyawan tersebut.

6. Stres kerja berpengaruh positif terhadap turnover intention. Maknanya adalah dengan meningkatnya stres kerja yang dirasakan karyawan, maka akan memicu peningkatan turnover intention dari karyawan tersebut.

7. Employee engagement berpengaruh negatif terhadap turnover intention. Maknanya adalah dengan meningkatnya employee engagement yang dirasakan karyawan, maka akan memicu penurunan turnover intention dari karyawan tersebut

8. Employee engagement memediasi variabel perceived organizational of support terhadap turnover intention dengan sifat melemahkan. Semakin karyawan merasa employee engagement, maka semakin rendah turnover intention karyawan.

9. Employee engagement memediasi variabel leader member exchange terhadap turnover intention dengan sifat melemahkan. Semakin karyawan merasa adanya employee engagement dari pihak perusahaan, maka semakin rendah turnover intention karyawan.

10. Employee engagement memediasi variabel stres kerja terhadap turnover intention dengan sifat melemahkan. Semakin karyawan merasa adanya employee engagement dari pihak perusahaan, maka semakin rendah turnover intention karyawan

\section{Saran}

1. Perusahaan hendaknya semakin terbuka dengan adanya Gen $\mathrm{Y}$ dalam angkatan kerja sekarang ini. Karakteristik yang berbeda dari generasi sebelumnya mengharuskan perusahaan untuk peduli terhadap usaha-usaha menurunkan tingkat turnover intention karyawan gen y, salah satunya dengan memperhatikan perceived organizational of support, leader-member exchange, stres kerja, dan employee engagement di tempat kerja.

2. Perceived organizational of support yang dirasakan oleh karyawan sebetulnya sudah baik, namun masih belum bisa menekan tingkat turnover intention secara keseluruhan. Hal tersebut dikarenakan gen $\mathrm{Y}$ butuh suatu pengkondisian yang berbeda. Perusahaan harus bisa memberikan hal yang berbeda dari perusahaan pesaing lainnya, misalnya dari segi penghargaan dan pengembangan karir, atau beasiswa pendidikan untuk karyawan yang berprestasi.

3. Leader-member exchange mempunyai peran yang penting terutama untuk mendukung dan mengarahkan karyawan gen $\mathrm{Y}$ dalam menjalankan pekerjaannya sehari-hari. Dari hasil penelitian ditemukan bahwa untuk meningkatkan pengaruh leader-member exchange maka perusahaan bisa membuat program-program kelas kecil untuk mendekatkan atasan dengan bawahan dan supaya tumbuh rasa kepercayaan atasan terhadap potensi 
karyawan gen Y. Sehingga gen Y akan merasa berarti dan diperhatikan sehingga tingkat turnover intention dapat di turunkan.

4. Stres kerja, sangat berpengaruh pada turnover intention karyawan. Dari hasil penelitian, stres kerja muncul karena karyawan tidak bisa mengikuti tuntutan kompetensi dari perusahaan. Salah satu solusinya, perusahaan dapat memberikan pelatihan-pelatihan khusus guna meningkatkan kompetensi dari karyawan tersebut.

5. Employee engagement terbukti dapat memediasi model persamaan dan cenderung menurunkan tingkat turnover intention dari karyawan. Dalam hal ini perusahaan harus mengkondisikan lingkungan tempat kerja, fasilitas, line managerial untuk saling mendukung demi terciptanya budaya employee engagement pada karyawan gen $\mathrm{Y}$.

\section{Keterbatasan Penelitian}

1. Data dari penelitian ini diperoleh dari pembagian kuesioner dengan skala 1-5. Penelitian ini sangat tergantung kepada interpretasi narasumber tentang keadaan yang tersirat dalam lingkungan kerja sehingga kecenderungan untuk bias masih tetap ada.

2. Penelitian masih dalam lingkup karyawan gen Y PT. BPR Restu Artha Makmur yang ada di Semarang, sehingga tidak bisa dianggap mewakili semua gen Y.

\section{Agenda Penelitian Mendatang}

1. Untuk penelitian mendatang sebaiknya dilakukan pada obyek penelitian yang berbeda baik dari segi bentuk usaha maupun lokasi obyek penelitian.

2. Pada penelitian selanjutnya sebaiknya mempertimbangkan untuk menambah variable lain yang merupakan kelanjutan maupun indikator lain dari turnover intention. 


\section{DAFTAR PUSTAKA}

Adijaya et al. 2015. Pengarug Stres Kerja, Kepuasan Kerja Dan Komitmen Organisasional Terhadap Turnover Intention Pada Karyawan Telkomsel Distribution Center Kabupaten Jember. Artikel Ilmiah 2015 Universitas Jember.

Anantatmula, V.S., \& Shrivastav, B. (2012). Evolution of Project Teams for Generation $Y$ Workforce. International Journal of Managing Projects in Business. $51: 9-26$

Caesens, F. Stinglhamber 2014. The relationship between perceived organizational support and work engagement: The role of self-efficacy and its outcomes. Elsevier masson france 259-267.

Chandra et al. 2016. Pengaruh Perceived Organizational Support dan Employee Engagement terhadap Turnover Intention Karyawan pada PT Wahana Wirawan. AGORA Vol. 4, No. 2

Chaurasia, S dan Archana Shukla. 2013. The Influence Of Leader-Member Exchange Relations On Employee Engagement And Work Role Performance International. Journal Of Organization Theory And Behavior, 16 (4), 465-493

Cran, C. (2014). 101 Tips Mengelola Generasi X, Y \& Zoomer Di Tempat Kerja. Jakarta: KPG.

Dwi, R. 2005. Hubungan Antara Stres Kerja Dengan Produktivitas Kerja Di Bagian Linting Rokok PT. Gentong Dotri Semarang. Jurnal Ekonomi Manajemen Vol.4(3) : 269-290.

Fah, C.B., Foon, S.Y., Leong, C., dan Osman, S. 2010. An Exploratory Study on Turnover Intention among Private Sector Employees. International Journal of Business and Management, Vol. 5 (8): 57-64.

Ghozali, I. 2011. Aplikasi Analisis Multivariatedengan program IBM SPSS 19. Semarang:Badan Penerbit Universitas Diponegoro.

Gitosudarmo I, Sudita N. 2000. Perilaku Keorganisasian. Yogyakarta (ID): BPFE

Imran et al. 2014. The Relationship between Perceived Organizational Support and Turnover Intention: Mediating Role of Affective Commitment and Job Satisfaction Research. Journal of Applied Sciences, Engineering and Technology 8(24): 2422-2425, 2014

John Smythe. 2007. The CEO; Chief Engagement Officer: turning hierarchy upside down to drive performance. England: Gowe Publishing Company

Kevin Kruse. 2012. Employee Engagement 2.0: How to Motivate Your Team for High Performance (A Real-World Guide for Busy Managers). Pennsylvania (US): The Kruse Group.

Ksama. I Made Artha Wibawa. 2016. Pengaruh Leader-Member Exchange, Role Stress Dan Perceived Organizational Support Terhadap Turnover Intention. E-Jurnal Manajemen Unud, Vol. 5, No. 10,: 6174-6200

Mangkunegara, P. 2009. Manajemen Sumber DayaManusia Perusahaan. Bandung: Rosda.

Manurung, M. T \& Ratnawati, I. 2012. AnalisisPengaruh Stres Kerja dan Kepuasan Kerjaterhadap Turnover Intention Karyawan:Studi pada 
STIKES Widya Husada Semarang.Diponegoro. Journal of Management.1 (2):145-157.

Ozdevecioglu et al. 2015. The Effect Of Leader-Member Exchange On Turnover Intention And Organizational Citizenship Behavior: The Mediating Role Of Meaningful Work. Proceedings Of The 9th International Management Conference "Management and Innovation For Competitive Advantage", November 5th-6th, 2015, Bucharest, Romania

Price, G., Bezuidenhout, L. 2005. Communication and leader-member exchange: a South African case study. 1-19.

Reilly, P. 2012. Understanding and teaching Generation Y. Journal English Teaching Forum.1(12). 21-31. Diunduh dari http://files.eric.ed.gov/fulltext/EJ971235.pdf

Rhoades \& Eisenberger. 2010. Perceived Organizational of Support: A Riview of The Literature. Jurnal of Apllied Psychology. Vol 87, No. 4, p 698-714..

Robbins, S. 2013. Organizational Behavior. Boston: Pearson Education Limited..

Salam, D. 2015. Cara memperlakukan Generasi Y di tempat kerja ala datascript. The-Marketeers.com. Diunduh dari http://marketeers.com/caramemperlakukan-generasi-y-di-tempat-kerja-a-la-datascrip/. 79

Sugiyono. 2008. Metode Penelitian Bisnis. Bandung: Alphabeta.

Tziner, Aharon et al. 2015. Work stress and turnover intentions among hospital physicians: The mediating role of burnout and work satisfaction. Journal of Work and Organizational Psychology 31 (2015) 207-213 